\title{
Timing of metamorphosis and estuarine arrival across the dispersal range of the Japanese eel Anguilla japonica
}

\author{
P. W. Cheng, W. N. Tzeng* \\ Department of Zoology, College of Science, National Taiwan University, No. 1, Sec. 4, Roosevelt Rd, \\ Taipei, Taiwan 10617, Republic of China
}

\begin{abstract}
Elvers of the Japanese eel Anguilla japonica Temminck \& Schlegel were collected from 6 estuaries in Taiwan, China and Japan. The fish were aged by counting otolith daily growth increments. The time of metamorphosis from leptocephali to glass eels was determined from the otolith increments where the width and strontium:calcium ratios changed drastically. Age upon arrival at the estuaries (mean $\pm \mathrm{SD}$ ) was $154.71 \pm 10.69$ to $182.06 \pm 12.43 \mathrm{~d}$, while age at metamorphosis was $115.8 \pm 8.13$ to $137.85 \pm 11.28 \mathrm{~d}$. Both ages showed a geographic cline that increased from south to north. The time from metamorphosis to arrival at the estuaries averaged $31.73 \pm 7.58$ to $45.02 \pm 9.21 \mathrm{~d}$. The lengthy duration of the leptocephalus stage and differences in the timing of metamorphosis are the principal factors in the long-distance dispersal of the eel.
\end{abstract}

KEY WORDS: Otolith Ageing Metamorphosis-Long-distance dıspersal Elver Japanese eel

\section{INTRODUCTION}

The Japanese eel Anguilla japonica Temminck \& Schlegel is a temperate catadromous fish, widely distributed in rivers of the northeastern Asian countries Taiwan, China, Korea and Japan (Tesch 1977). Development of the Japanese eel includes 5 stages, i.e. the leptocephalus, glass eel, elver, yellow eel and silver eel stages, similar to those of Anguilla anguilla (Bertin 1956). The Japanese eel was presumed to originate from the same panmictic population (Sang et al. 1994), and its spawning grounds were recently discovered in the North Equatorial Current west of the Mariana Islands, $15^{\circ} \mathrm{N}, 140^{\circ} \mathrm{E}$ (Tsukamoto 1992). The leptocephali drift with the North Equatorial Current from their spawning grounds. When they approach the continental shelf of the Philippines, they turn northward into the Kuroshio Current conveyed by the mechanism of Ekman transport (Kimura et al. 1994). After reaching a fully grown size, leptocephaii metamorphose in to the glass eel stage and leave the strong Kuroshio Current

\footnotetext{
-Addressee for correspondence and reprint requests.
}

E-mail: wnt@ccms.ntu.edu.tw
(Tsukamoto 1990). The glass eels become elvers upon arrival at estuaries. The elvers arrive at estuaries spread over an area of approximately $2000 \mathrm{~km}$ from south to north (Fig 1). The mechanism determining the long-distance dispersal of the glass eel still remains open to discussion.

The body of a leptocephalus is shaped like a willowleaf, suitable for long-distance dispersal by a current. Accordingly, the timing of metamorphosis seems to be important in determining the geographic distribution of the eel. However, the collection of leptocephali is very difficult (Tanak 1975, Kajihara et al. 1988). The criterion for ascertaining the age of metamorphosis of a leptocephalus to a glass eel has been controversial (Tsukamoto \& Umezawa 1990, Leomte-Finiger 1992), and there has been little use of otoliths in determining the early life history of the glass eel. Recent studies indicate that the age of the eel at metamorphosis can be determined by changes in otolith microstructures as well as by changes in the strontium:calcium (Sr:Ca) ratios in the daily growth increments of the otolith (Tzeng \& Tsai 1992, 1994, Otake et al. 1994, Tzeng 1995). These findings suggest that it is possible to reconstruct early life-history events from otoliths. 


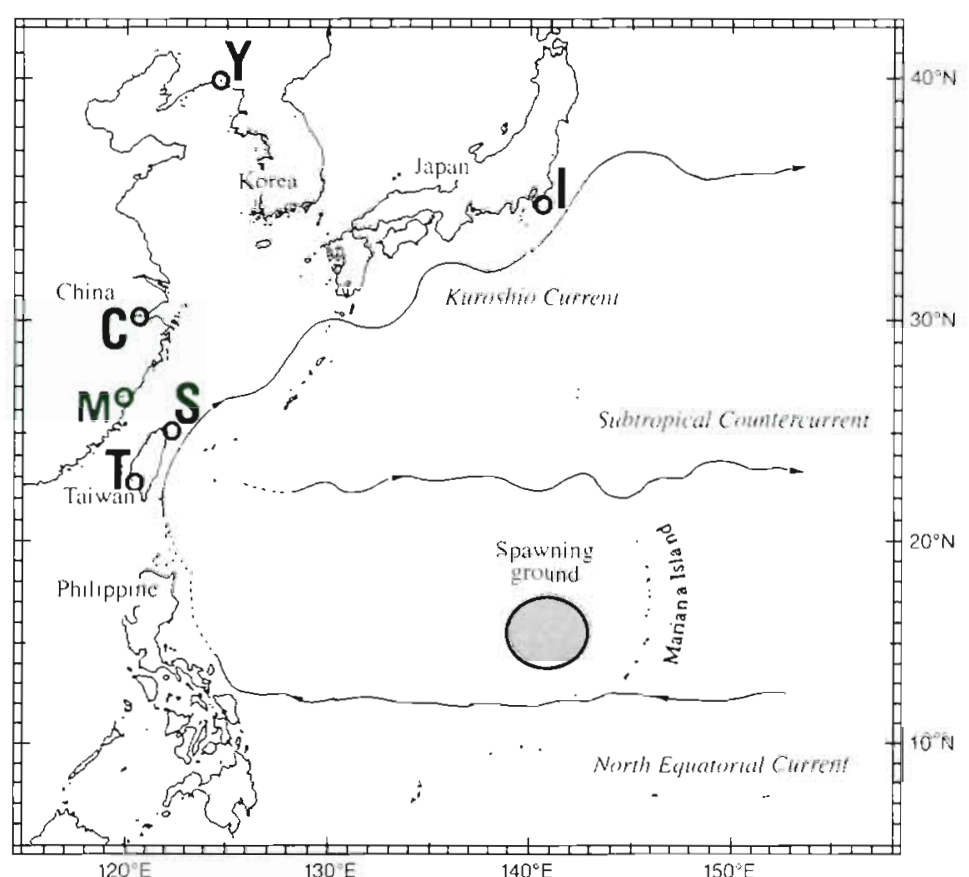

Fig. 1. Map showing oceanic currents and 6 estuaries where elvers were collected. C: Chyan-Tarng River; I: Ichinomiya River; M: Ming-Chiang River; $S\left(S_{1} \& S_{2}\right)$ : Shuang-Shi River; $T\left(T_{1} \& T_{2}\right)$ : Tung-Kang River; Y. YaLu River

This study attempts to determine the age of Anguilla japonica at metamorphosis from leptocephali to glass eels. These ages are used to understand the contribution of the lengthy leptocephalus stage and time delay in metamorphosis to the long-distance dispersal of Japanese eel larvae.

\section{MATERIALS AND METHODS}

A total of 240 elvers were collected from 6 estuaries: the Tung-Kang and Shuang-Shi rivers in Taiwan, the Ming-Chiang and Chyan-Tarng rivers in China, the Ichinomiya River in Japan and the Ya-Ru River between Korea and China (Fig 1). The elvers were collected using dip nets during nightime flood tides. The sampling dates are listed in Table 1 Total length (TL) of elvers was measured to the nearest $0.01 \mathrm{~mm}$ after fixation in $95 \%$ alcohol for $1 \mathrm{wk}$. Using $30 \mathrm{sam}$ ples of various ages, the length relationship before $(Y)$ and after $(X)$ fixation is

$$
Y=-0.14+1.04 X \quad(\mathrm{r}=0.94) .
$$

This equation was used to adjust the length due to alcohol fixation.

The pigmentation stages, which are important to determine the developmental stages from glass eel to elver, were assessed according to the distribution of pigments on the body surfaces (Strubberg 1913). Newly arrived elvers in coastal waters are in stage $V_{A}$ and there are no external pigments on their body surfaces except the caudal spot. The skull spot appears at stage $V_{B}$; after this stage the eel abandons its purely pelagic existence. In stage $\mathrm{VI}_{B}$ the eel loses its glass-like transparency (Tesch 1977). To precisely determine age upon arrival at an estuary, elvers in the earlier stages of pigmentation were selected for age determination.

The otolith (sagitta) was extracted from the vestibular apparatus, its maximum length was measured along the anteroposterior axis with a computer-aided image analysis system (VIPRO 512), and it was then embedded in resin. The radii were measured from scanning electron microscopy (SEM) micrographs at $300 \times$ magnification along the maximum axis of the otolith sectioned on the sagittal plane of the fish (Fig. 2). Daily growth increments in otoliths were counted on SEM micrographs at a magnification of $2000 \times$. $\mathrm{Sr}$ and $\mathrm{Ca}$ concentrations in the otoliths were measured from the primordium to the otolith edge using an electron microprobe equipped with a 4-channel wavelength-dispersive spectrometer (WDS; Shimadzu-ARL EMX-SM). Procedures for embedding, sectioning, polishing, coating and etching otoliths for SEM and WDS followed those described by Tzeng (1990) and Tzeng \& Tsai $(1992,1994)$.

The age of an elver was determined according to the number of daily growth increments in the otolith (Tzeng 1990, Tzeng \& Tsai 1992). The age at metamorphosis from a leptocephalus to a glass eel was estimated from the number of daily growth increments in the otolith of the elver counted from the primordium to the metamorphosis check, where otolith increment width suddenly became narrow and the Sr:Ca ratio suddenly decreased (Otake et al. 1994, Tzeng \& Tsai 1994. Tzeng 1995). To estimate the actual age of metamorphosis, $5 \mathrm{~d}$ were added to the number of the daily growth increments, because no increment is deposited in the core of the otolith during the yolk-sac stage for 5 d (Tzeng 1990, Tzeng \& Tsai 1992). The amount of time between metamorphosis and migration to the estuaries was calculated by the number of daily growth increments between the metamorphosis check and the edge of the otolith.

Because counting daily growth increments in otoliths was time consuming, and the increments at and 
Table 1 Anguilla japonica. Total lengths and pigmentation stages of elvers collected from the 6 estuaries. Sampling sites shown in Fig. 1

\begin{tabular}{|c|c|c|c|c|c|c|c|c|c|}
\hline \multirow{2}{*}{$\begin{array}{l}\text { Sampling } \\
\text { site }\end{array}$} & \multirow{2}{*}{$\begin{array}{l}\text { Sampling } \\
\text { date }\end{array}$} & \multirow{2}{*}{$\begin{array}{c}\text { Sample } \\
\text { size }\end{array}$} & \multicolumn{2}{|c|}{ Total length $(\mathrm{mm})$} & \multicolumn{5}{|c|}{ Pigmentation stages $(\%)$} \\
\hline & & & Range & Mean $\pm S D$ & $V_{A}$ & $\dot{\mathrm{V}}_{\mathrm{B}}$ & $V I_{A 1}$ & $\mathrm{VI}_{\mathrm{A} 2}$ & $\mathrm{VI}_{\mathrm{A} 3}$ \\
\hline $\mathrm{T}_{1}$ & 30 Dec 1992 & 30 & $53.54-60.49$ & $56.96 \pm 1.9$ & 95 & 5 & & & \\
\hline $\mathrm{T}_{2}$ & $24 \operatorname{Mar} 1993$ & 30 & $51.29-60.14$ & $56.07 \pm 2.4$ & 83.3 & 16.7 & & & \\
\hline $\mathrm{S}_{1}$ & 30 Dec 1992 & 30 & $50.99-60.85$ & $56.84 \pm 2.31$ & 45 & 55 & & & \\
\hline $\mathrm{S}_{2}$ & 17 Feb 1993 & 30 & $51.77-59.19$ & $55.98 \pm 2.15$ & 33.3 & 56.6 & 10 & & \\
\hline$M$ & 1 Mar 1993 & 30 & $51.67-59.0$ & $55.07 \pm 1.87$ & 83 & 17 & & & \\
\hline $\mathrm{C}$ & 17 Feb 1993 & 30 & $51.16--59.23$ & $55.6 \pm 1.87$ & 70 & 30 & & & \\
\hline$Y$ & 3 May 1993 & 30 & $55.07-60.68$ & $58.3 \pm 1.8$ & & 3.3 & 73 & 20 & 3.3 \\
\hline I & $10 \mathrm{Jan} 1994$ & 30 & $51.31-62.17$ & $57.41 \pm 2.3$ & 19.4 & 66.7 & 9.7 & 3.2 & \\
\hline
\end{tabular}

near the metamorphosis area were often diffusive and obscure, a subsample of otoliths with clear daily growth increments was selected for age-determination (Table 2) and their mean otolith growth increment widths on the corresponding radii were calculated. Then, the age at metamorphosis $\left(T_{\mathrm{m}}\right)$ was calculated from mean increment width and otolith radius by the following equation:

$$
T_{\mathrm{m}}=M_{\mathrm{r}}+t_{\mathrm{yk}}=\left(R_{\mathrm{m}}-R_{\mathrm{c}}\right) / W_{R_{\mathrm{m}}}+t_{\mathrm{yk}}
$$

where $M_{r}$ is the number of daily growth increments from the outer core to the metamorphosis check; $R_{\mathrm{m}}$ and $R_{c}$ are the radii from the primordium to the metamorphosis check and to the outer core, respectively (Fig. 2); $W_{R_{\mathrm{m}}}$ is the mean otolith growth increment width on $R_{\mathrm{m}}$ and $t_{y k}$ is the duration of the yolk-sac period before a growth increment was deposited in the

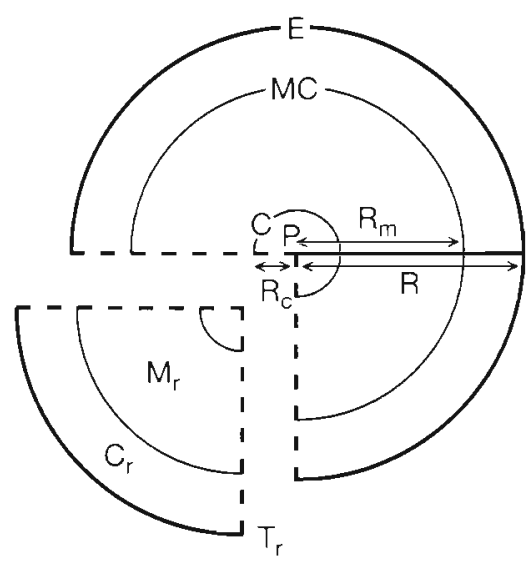

Fig. 2. Anguilla japonica. Schematic diagram of measurements of radii and counts of dally growth increments in otoliths of elvers. P; primordıum; C: core; $\mathrm{MC}$ : metamorphosis check; E: edge; $R_{\mathrm{C}}, R_{\mathrm{m}}$ and $R$ : radil from primordium to the outer core, to the metamorphosis check and to the otolith edge, respectively; $M_{r}, T_{r}$ and $C_{r}$ : counts of daily growth increments corresponding to the radil of $R_{\mathrm{m}}$ and $R$ and the section between $\mathrm{MC}$ and $\mathrm{E}$, respectively core of the otholith (approximately $5 \mathrm{~d}$ ). Similarly, the amount of time between metamorphosis and migration to the estuaries, i.e. the number of daily growth increments between the metamorphosis check and the edge of the otolith $\left(C_{r}\right)$, was estimated by the equation:

$$
C_{r}=\left(R-R_{\mathrm{m}}\right) / W_{\left(R-R_{\mathrm{m}}\right)}
$$

where $R$ is the radius from the primordium to the edge of the otolith and $W_{\left[R-R_{\mathrm{m}}\right)}$ is the mean increment width on the otolith from the metamorphosis check (MC) to the edge (E) (Fig. 2). Then, the age of an elver upon arrival at an estuary $\left(T_{\mathrm{r}}\right)$ equals $T_{\mathrm{m}}$ plus $C_{r}$.

The homogeneity of $T_{\mathrm{m}}, T_{\mathrm{r}}$, and $C_{r}$ among estuaries was tested with Scheffe's multiple range analysis (Sokal \& Rohlf 1981). Correlation coefficients were calculated among fish lengths, pigmentation stages, otolith maximum lengths, otolith radii at metamorphosis, age at metamorphosis, age upon arrival at the estuaries, and the amount of time needed for migration to the estuaries after metamorphosis.

Table 2. Anguilla japonica. Counts of daily growth increments (mean $+\mathrm{SD}$ ) in otoliths of elvers collected from the 6 estuaries. (T, S, M, C, Y and I) shown in Fig. 1. $M_{r}, C_{r}$ and $T_{r}$ : counts of daily growth increments corresponding to the radii of $R_{\mathrm{m}}, R-R_{\mathrm{rn}}$ and $R$ as shown in Fig. 2. Sample sizes

\begin{tabular}{|c|c|c|c|}
\hline \multirow{2}{*}{$\begin{array}{l}\text { Sampling } \\
\text { site }\end{array}$} & \multicolumn{3}{|c|}{ Otolith growth increment } \\
\hline & $M_{\tau}$ & $C_{r}$ & $I_{r}$ \\
\hline $\mathrm{T}_{1}$ & $144.8 \pm 11.1$ (7) & $41.6 \pm 9.0$ & $186.4 \pm 12.5$ \\
\hline $\mathrm{T}_{2}$ & $133.9 \pm 8.0$ & $39.4 \pm 2.4 \quad(5)$ & $172.0 \pm 5.9$ \\
\hline $\mathrm{S}_{1}$ & $147.1 \pm 15.7$ & $42.2 \pm 6.0$ & $189.0 \pm 16.4$ \\
\hline $\mathrm{S}_{2}$ & $134.3 \pm 17.7$ & $35.0 \pm 5.7$ & $175.3 \pm 11.1$ \\
\hline$\dot{M}$ & $141.5 \pm 9.8$ & $34.2 \pm 6.8$ (6) & $177.6 \pm 12.6 \quad(6)$ \\
\hline $\mathrm{C}$ & $151.7 \pm 10.6(12)$ & $44.3 \pm 8.0$ & $198.3 \pm 6.9$ \\
\hline Y & $159.7 \pm 8.3$ & $41.8 \pm 9.0(11)$ & $201.5 \pm 11.9(11)$ \\
\hline 1 & $147.6 \pm 7.2$ & $40.6 \pm 10.5(7)$ & $189.7 \pm 9.2$ \\
\hline
\end{tabular}
in parentheses 

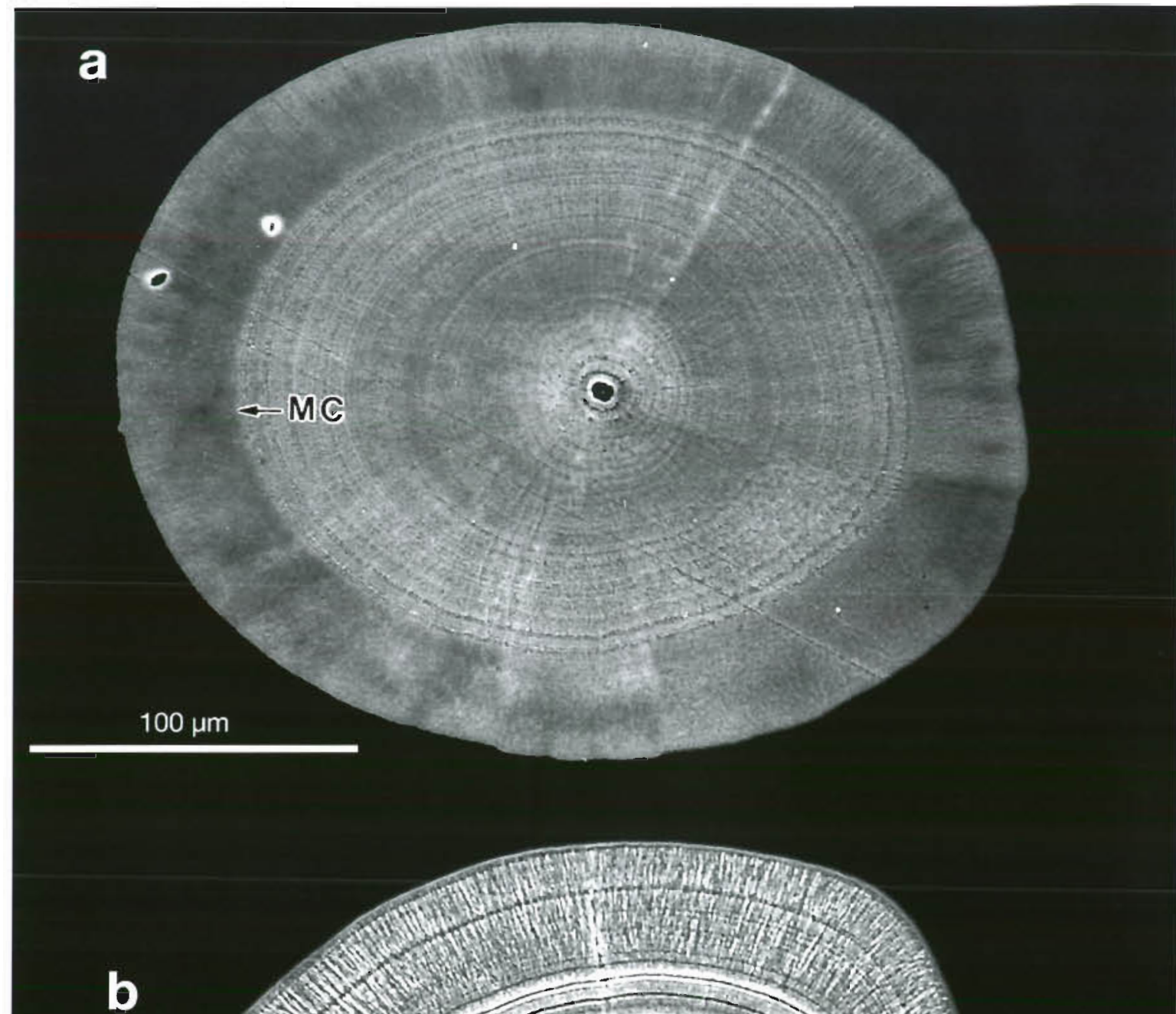

b

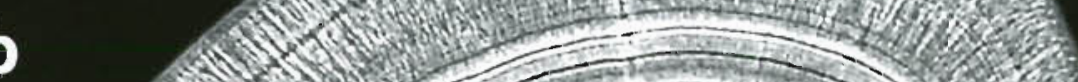
Quing
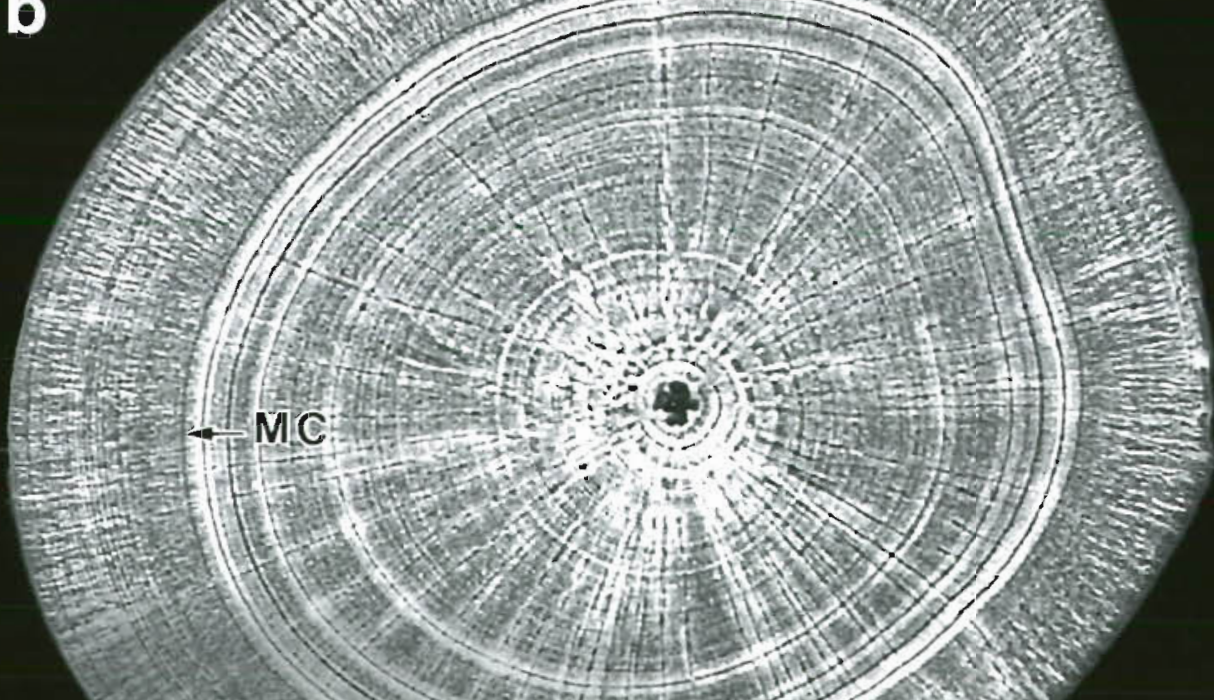

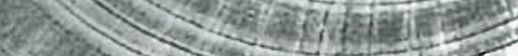

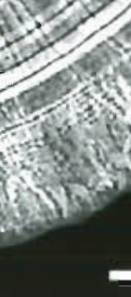


Fig. 3. Anguilla japonica. SEM micrograph illustrating changes in (a) phase contrast and (b) incremental patterns in otoliths of elvers during metamorphosis. (a) $55.1 \mathrm{~mm}$ TL collected from the Tung-Kang River estuary on 24 February 1993 ; (b) $56.68 \mathrm{~mm}$ TL from the same estuary on 30 December 1992. MC: metamorphosis check

\section{RESULTS}

\section{Size and pigmentation stage of elvers}

Total lengths of elvers arriving at the 6 estuaries ranged from 50.99 to $62.17 \mathrm{~mm}$, with averages of $55.07 \pm 1.87$ to $58.3 \pm 1.8 \mathrm{~mm}$ (Table 1 ). The elvers from the Ya-Lu River estuary in northern China were significantly longer than those from other estuaries ( $t$-test, $p<0.01$ ), but those from other estuaries showed no significant difference ( $t$-test, $p>0.05$ ). Most newly recruited elvers in the estuaries were in the pigmentation stages $V_{A}$ and $V_{B}$. The occurrence of larger elvers in the Ya-Lu River estuary corresponded with their more advanced stages of pigmentation $\left(\mathrm{VI}_{\mathrm{A} 1}\right.$ and $\left.\mathrm{VI}_{\mathrm{A} 2}\right)$ (Table 1). There was a significant correlation between $\mathrm{TL}$ and the pigmentation stage of elvers $(\mathrm{r}=0.32$, $\mathrm{df}=139, \mathrm{p}<0.0001)$.

\section{Otolith microstructure and age determination}

The microstructure of the otoliths of elvers showed obvious changes in phase contrast and crystal patterns (Fig. 3). The brightness of the SEM otolith micrograph became darker beyond the MC (Fig, 3a), and the incremental pattern changed from a circular form to a radial form beyond the check (Fig. 3b). The increment widths gradually decreased beginning at approximately the 30 th daily growth increment from the primordium and became smallest at the presumed MC, between approximately the 120 th and the 150th daily growth increments from the primordium; beyond the check the increment widths drastically increased (Fig. 4). These morphological changes corresponded with the drastic change in $\mathrm{Sr}$ contents or Sr:Ca ratios in the otolith as described in a previous study (Tzeng \& Tsai 1994), which associated the change with metamorphosis from a leptocephalus to a glass eel (Otake et al. 1994). The leptocephalus is known to contain numerous gelatinous extracellular matrixes composed of sulfated glycosaminoglycans (GAG), which are broken down during the process of metamorphosis (Pfeiler 1984, 1986, 1991). GAG exhibits an affinity to alkali earth elements and, in particular, to Sr (Nishizawa 1978). GAG breakdown may reduce the absorption of Sr and result in a drastic decrease in otolith Sr contents and, consequently, in Sr:Ca ratios. Thus, the number of daily growth increments in the otolith, the timing of the drastic changes in the otolith microstructural pattern, and changes in Sr:Ca ratios in the otolith were used to estimate the age of metamorphosis from leptocephali to glass eels. Fig. 5 shows daily growth increments in the otolith of a $56.5 \mathrm{~mm}$ TL elver collected from the Chyan-Tarng River estuary on 27 Febuary 1993. The fish metamorphosed at approximately $158 \mathrm{~d}$ after hatching and took approximately $33 \mathrm{~d}$ to migrate to the estuary after the metamorphosis. The elver arrived at the estuary at approximately $191 \mathrm{~d}$ after hatching.

Mean ( \pm SD) daily growth increments in otoliths from a subsample of elvers from the 6 estuaries are shown in Table 2. Actual age at metamorphosis and upon arrival at the estuaries was based on the counts of daily growth increments plus the $5 \mathrm{~d}$ yolk-sac period.

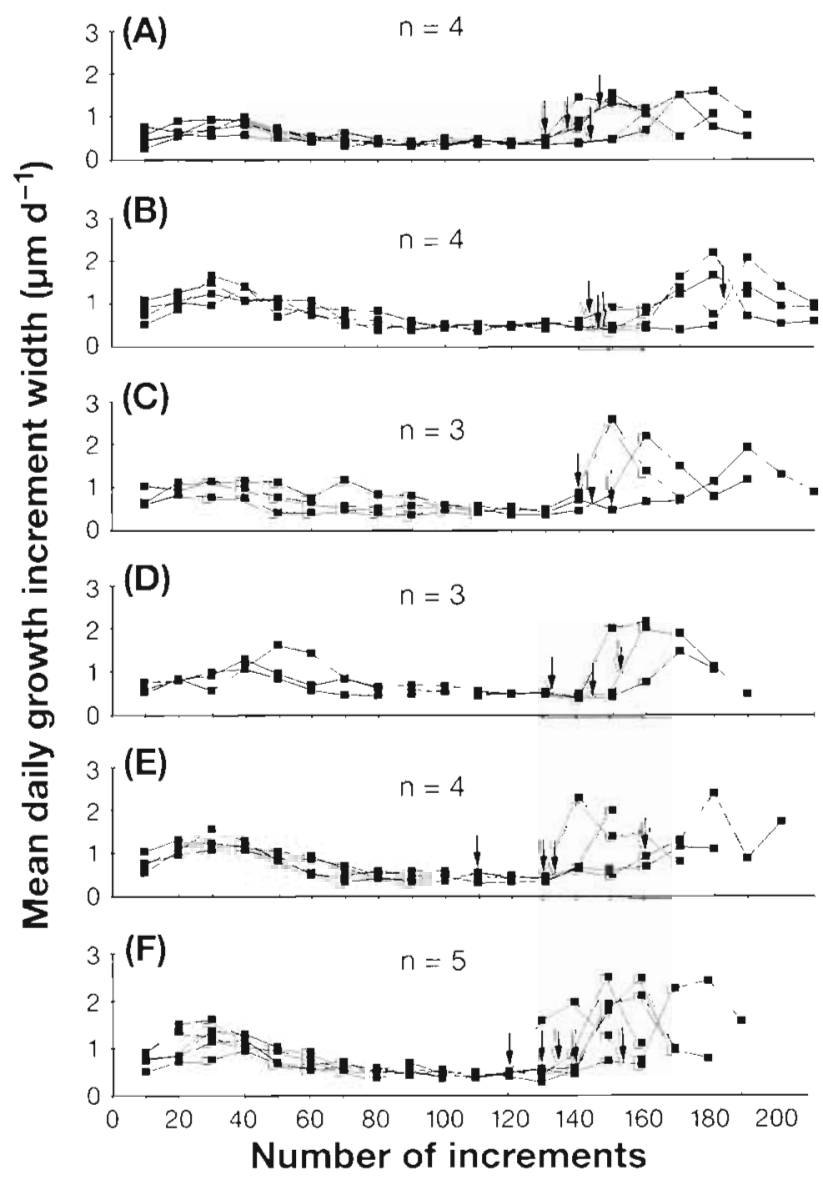

Fig. 4. Angulla japonica. Temporal changes in mean daily growth increment widths of otoliths of elvers collected from 6 estuaries: (A) Ichinomiya River; (B) Ya-Lu River; (C) ChyanTarng River; (D) Ming-Chiang River; (E) Shuang-Shi River; (F) Tung-Kang River. Arrows: locations of metamorphosis check; n: sample size 


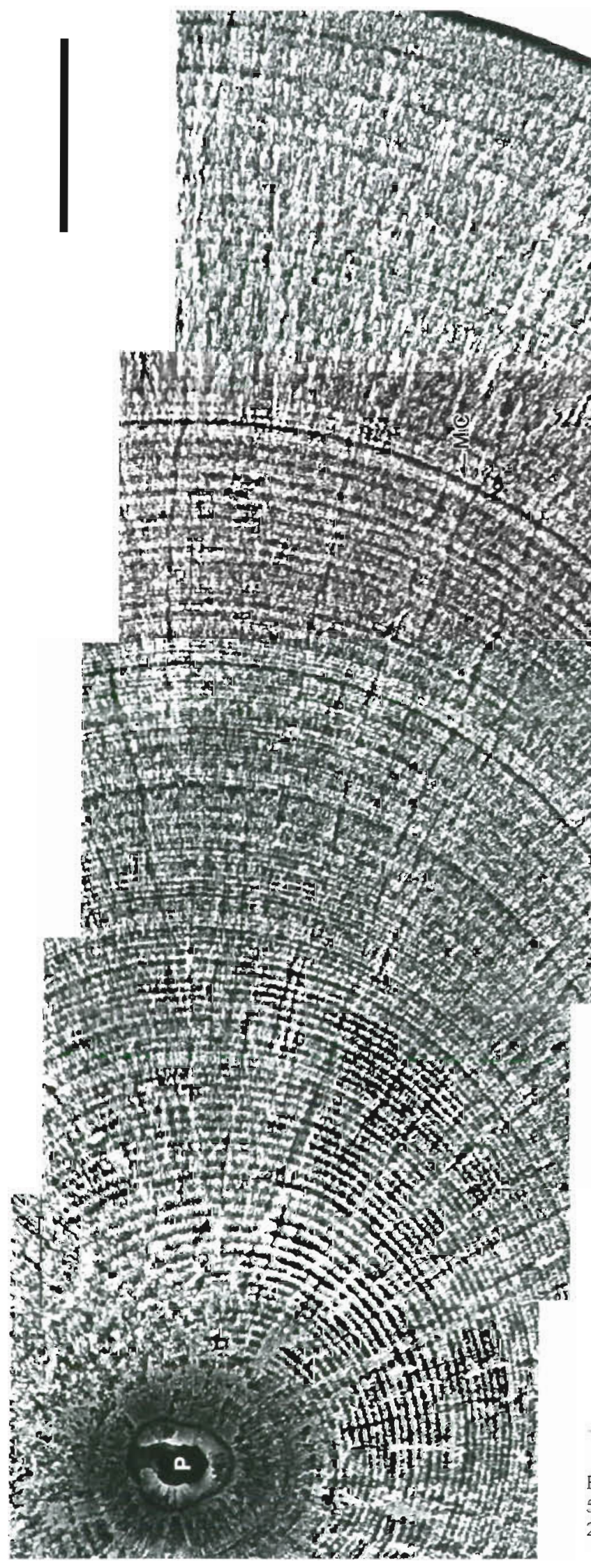

Otolith radius and increment width

Otolith radii of elvers at different phases of their early life history (Fig. 2) are shown in Table 3. The radii were $8.91 \pm 1.33 \mu \mathrm{m}$ (Sampling Site I in Japan) to $10.28 \pm 0.85 \mu \mathrm{m}$ (Site $\mathrm{T}_{1}$ in Taiwan) for the cores $\left(R_{c}\right), 98.16 \pm$ $9.07 \mu \mathrm{m}$ (Site $\mathrm{T}_{2}$ in Taiwan) to $108.52 \pm$ $8.18 \mu \mathrm{m}$ (Site $\mathrm{Y}$ in China) for the metamorphosis checks $\left(R_{\mathrm{m}}\right)$, and $142.86 \pm 12.04 \mu \mathrm{m}$ (Site $\mathrm{T}_{2}$ ) to $163.22 \pm 8.72 \mu \mathrm{m}$ (Site $\mathrm{Y}$ ) for the maximum radii $(R)$. The otolith maximum lengths were $299.73 \pm 13.16 \mu \mathrm{m}$ (Site $\mathrm{T}_{1}$ ) to $317.98 \pm 13.27 \mu \mathrm{m}$ (Site Y). The otoliths were larger for fish captured in estuaries farther from the spawning grounds, but the cores were smaller.

Mean otolith growth increment widths of elvers at different phases of their early life history are shown in Table 4. Before metamorphosis the mean otolith growth increment widths showed a geographic cline, decreasing from south to north (Table 4B), but after metamorphosis the mean increment widths were homogenous among the 6 estuaries (Table $4 \mathrm{C}$ ).

The number of daily growth increments from the outer core to the metamorphosis check $(Y)$ was negatively correlated with the mean increment width $(X)(Y=224.759$ $110.77 X_{i} r=-0.71, n=37$ ). This indicates that fast-growing leptocephali metamorphosed earlier.

Geographic cline in age at metamorphosis and arrival at estuaries

Age upon arrival at the estuaries differed among the 6 estuaries with the shortest period being $154.71 \pm 10.69 \mathrm{~d}$ in Taiwan (Site $\mathrm{S}_{2}$ ) and the longest period $182.06 \pm$ $12.43 \mathrm{~d}$ in Japan (Site I), an average difference of $27.35 \mathrm{~d}$. Age at metamorphosis was $115.80 \pm 8.13$ to $137.85 \pm 11.28 \mathrm{~d}$, a difference of $22 \mathrm{~d}$ (Table 5). The eel had a lengthy leptocephalus stage during oceanic passive migration, and there was a geographic cline

Fig. 5. Anguilla japonica. Daily growth increments in otolith of a $56.5 \mathrm{~mm}$ TL elver collected from the Chyan-Tang River estuary on 27 February 1993. P: primordium; MC: metamorphosis check. Scale bar $=20 \mu \mathrm{m}$ 
Table 3. Anguilla japonica. Otolith length and radil (mean \pm SD) of elvers collected from the 6 estuaries (T, S, M, C, Y and I) shown in Fig. 1. $R_{6}, R_{\mathrm{m}}$, and $R$ are defined in Fig. 2. Sample sizes in parentheses

\begin{tabular}{|c|c|c|c|c|}
\hline $\begin{array}{l}\text { Sampling } \\
\text { sites }\end{array}$ & $R_{c}$ & $\begin{array}{l}\text { Radii }(\mu \mathrm{m}) \\
R_{\mathrm{m}}\end{array}$ & $R$ & $\begin{array}{c}\text { Otolith } \\
\text { length }(\mu \mathrm{m})\end{array}$ \\
\hline$T_{1}$ & $10.28 \pm 0.85(15)$ & $103.85 \pm 11.11(16)$ & $149.94 \pm 15.55(26)$ & $299.73 \pm 13.16(11)$ \\
\hline$T_{2}$ & $9.33 \pm 0.91(14)$ & $98.16 \pm 9.07$ & $142.86 \pm 12.04(14)$ & $300.58 \pm 17.84(13)$ \\
\hline $\mathrm{S}_{1}$ & $9.76 \pm 1.34(11)$ & $107.10 \pm 11.31(12)$ & $155.44 \pm 19.21(12)$ & $304.85 \pm 22.96(10)$ \\
\hline $\mathrm{S}_{2}$ & $9.49 \pm 1.08(13)$ & $105.45 \pm 7.07$ & $158.64 \pm 11.41(13)$ & $305.42 \pm 15.98(13)$ \\
\hline M & $9.63 \pm 0.90(20)$ & $101.80 \pm 5.00 \quad(20)$ & $150.43 \pm 8.11$ & $301.72 \pm 14.99(18)$ \\
\hline $\mathrm{C}$ & $9.00 \pm 1.14(23)$ & $101.46 \pm 7.90$ & $150.93 \pm 9.37$ & $309.11 \pm 13.14(21)$ \\
\hline $\mathrm{Y}$ & $9.61 \pm 1.05(23)$ & $108.52 \pm 8.18$ & $163.22 \pm 8.72$ & $317.98 \pm 13.27(21)$ \\
\hline I & $8.91 \pm 1.33$ & $106.52 \pm 8.68 \quad(10)$ & $159.02 \pm 11.87(10)$ & $306.85 \pm 23.28(10)$ \\
\hline
\end{tabular}

in age at metamorphosis that increased from south to north (Fig. 6B). The duration of the migration from the time of metamorphosis to the time of arrival at the estuaries was $31.73 \pm 7.58$ to $45.02 \pm 9.21 \mathrm{~d}$ (Table 5 ). This duration also showed a geographic cline that increased from south to north except at Sites $T_{1}$ and $T_{2}$ in southern Taiwan (Fig. 6C).

Table 4. Anquilla japonica. Homogeneity test for increment widths (mean $\pm \mathrm{SD}$ ) on the radii of (A) $R,(\mathrm{~B}) R_{\mathrm{m}}$ and (C) $R-R_{\mathrm{m}}$ in otoliths of elvers collected from the 6 estuaries. $R, R_{\mathrm{m}}$ and $R-R_{\mathrm{m}}$ are defined in Fig. 2. The 6 estuaries (T, S, M, C, $Y$ and 1) are shown in Fig. 1 Asterisks shared between sampling sites indicate they are the same homogeneous group

\begin{tabular}{|c|c|c|c|}
\hline $\begin{array}{l}\text { Sampling } \\
\text { site }\end{array}$ & $\begin{array}{l}\text { Sample } \\
\text { size }\end{array}$ & $\begin{array}{c}\text { Increment width } \\
(\mu \mathrm{m})\end{array}$ & $\begin{array}{l}\text { Homogeneous } \\
\text { group }\end{array}$ \\
\hline \multicolumn{4}{|l|}{ (A) $R$} \\
\hline $\mathrm{T}_{2}$ & 5 & $0.813 \pm 0.030$ & - \\
\hline$C^{2}$ & 4 & $0.815 \pm 0.032$ & - \\
\hline I & 5 & $0.835 \pm 0.048$ & $\cdots$ \\
\hline Y & 8 & $0.860 \pm 0.052$ & $\cdots$ \\
\hline M & 5 & $0.869 \pm 0.064$ & $\cdots$ \\
\hline $\mathrm{T}_{1}$ & 5 & $0.904 \pm 0.087$ & $\cdots$ \\
\hline$S_{1}$ & 6 & $0.934 \pm 0.028$ & $\cdot \cdot$ \\
\hline $\mathrm{S}_{2}$ & 2 & $1.034 \pm 0.036$ & $\cdot$ \\
\hline \multicolumn{4}{|l|}{ (B) $R_{\mathrm{m}}$} \\
\hline C & 7 & $0.696 \pm 0.075$ & • \\
\hline I & 5 & $0.746 \pm 0.063$ & $\cdots$ \\
\hline M & 5 & $0.749 \pm 0.020$ & $\cdots$ \\
\hline $\mathrm{Y}$ & 8 & $0.761 \pm 0.086$ & $\cdots$ \\
\hline$T_{2}$ & 7 & $0.766 \pm 0.071$ & $\cdots$ \\
\hline$S_{1}$ & 7 & $0.812 \pm 0.071$ & $\cdots$ \\
\hline $\mathrm{T}_{1}$ & 5 & $0.836 \pm 0.071$ & $\cdots$ \\
\hline $\mathrm{S}_{2}$ & 3 & $0.870 \pm 0.087$ & $\cdot$ \\
\hline \multicolumn{4}{|l|}{ (C) $R-R_{\mathrm{m}}$} \\
\hline $\mathrm{T}_{2}$ & 5 & $1.042 \pm 0.185$ & - \\
\hline l & 5 & $1.166 \pm 0.262$ & $\cdot$ \\
\hline T: & 5 & $1.177 \pm 0.311$ & - \\
\hline $\mathrm{Y}$ & 8 & $1.277 \pm 0.454$ & - \\
\hline C & 4 & $1.280 \pm 0.167$ & - \\
\hline $\mathrm{S}_{2}$ & 2 & $1.367 \pm 0.029$ & - \\
\hline$M$ & 5 & $1.410 \pm 0.383$ & · \\
\hline $\mathrm{S}_{1}$ & 6 & $1.523 \pm 0.481$ & $\cdot$ \\
\hline
\end{tabular}

\section{DISCUSSION}

The age of metamorphosis from a leptocephalus to a glass eel for the Japanese eel was determined by Tsukamoto \& Umezawa (1990) to be on the average between 85 and $97 \mathrm{~d}$, which is less than the 116 to $138 \mathrm{~d}$ estimated by our study (Table 5 ). This discrep-

Table 5. Anguilla japonica. Homogeneity test for (A) age of elvers arriving at the 6 estuaries, $(B)$ age of leptocephali at metamorphosis, and (C) time between metamorphosis and arrival at the estuaries. The 6 estuares ( $T, S, M, C, Y$ and I) are shown in Fig. 1. Asterisks shared between sampling sites indicate they are the same homogeneous group

\begin{tabular}{|c|c|c|c|}
\hline $\begin{array}{l}\text { Sampling } \\
\text { site }\end{array}$ & $\begin{array}{l}\text { Sample } \\
\text { size }\end{array}$ & $\begin{array}{l}\text { Age } \\
\text { (d) }\end{array}$ & $\begin{array}{c}\text { Homogeneous } \\
\text { group }\end{array}$ \\
\hline \multicolumn{4}{|c|}{ (A) Age of elvers } \\
\hline $\mathrm{S}_{2}$ & 13 & $154.71 \pm 10.69$ & - \\
\hline $\mathrm{T}_{1}$ & 16 & $156.86 \pm 17.44$ & $\cdot$ \\
\hline $\mathrm{S}_{1}$ & 12 & $157.61 \pm 18.78$ & $\cdot$ \\
\hline M & 20 & $162.87 \pm 8.59$ & · \\
\hline $\mathrm{T}_{2}$ & 14 & $164.29 \pm 14.17$ & . \\
\hline$C^{2}$ & 23 & $176.49 \pm 11.34$ & - \\
\hline $\mathrm{Y}$ & 23 & $178.35 \pm 9.94$ & - \\
\hline$i$ & 10 & $182.06 \pm 12.43$ & $\cdot$ \\
\hline \multicolumn{4}{|c|}{ (B) Age of leptocephali } \\
\hline $\mathrm{S}_{2}$ & 13 & $115.80 \pm 8.13$ & $\cdot$ \\
\hline $\mathrm{T}:$ & 16 & $117.70 \pm 14.26$ & $\cdots$ \\
\hline $\mathrm{T}_{2}$ & 14 & $121.39 \pm 12.04$ & $\cdots$ \\
\hline$S_{1}$ & 12 & $125.88 \pm 14.7$ & $\cdots$ \\
\hline M & 20 & $128.38+686$ & $\cdots$ \\
\hline Y & 23 & $135.52 \pm 11.28$ & $\cdots$ \\
\hline 1 & 10 & $137.04 \pm 12.89$ & $\cdots$ \\
\hline $\mathrm{C}$ & 23 & $137.85 \pm 11.28$ & $\cdot$ \\
\hline \multicolumn{4}{|c|}{ (C) Time from metamorphosis to estuaries } \\
\hline$S_{1}$ & 12 & $31.73 \pm 7.58$ & - \\
\hline M & 20 & $34.49 \pm 3.62$ & $\cdots$ \\
\hline $\mathrm{C}$ & 23 & $38.64 \pm 5.72$ & • \\
\hline$S_{2}$ & 13 & $38.91 \pm 5.82$ & $\cdots$ \\
\hline$T_{i}$ & 16 & $39.16 \pm 6.83$ & $\cdots$ \\
\hline$Y^{\prime}$ & 23 & $42.83 \pm 7.36$ & $\cdot \cdot$ \\
\hline $\mathrm{T}_{2}$ & 14 & $42.90 \pm 6.20$ & $\cdots$ \\
\hline I & 10 & $45.02 \pm 9.21$ & • \\
\hline
\end{tabular}



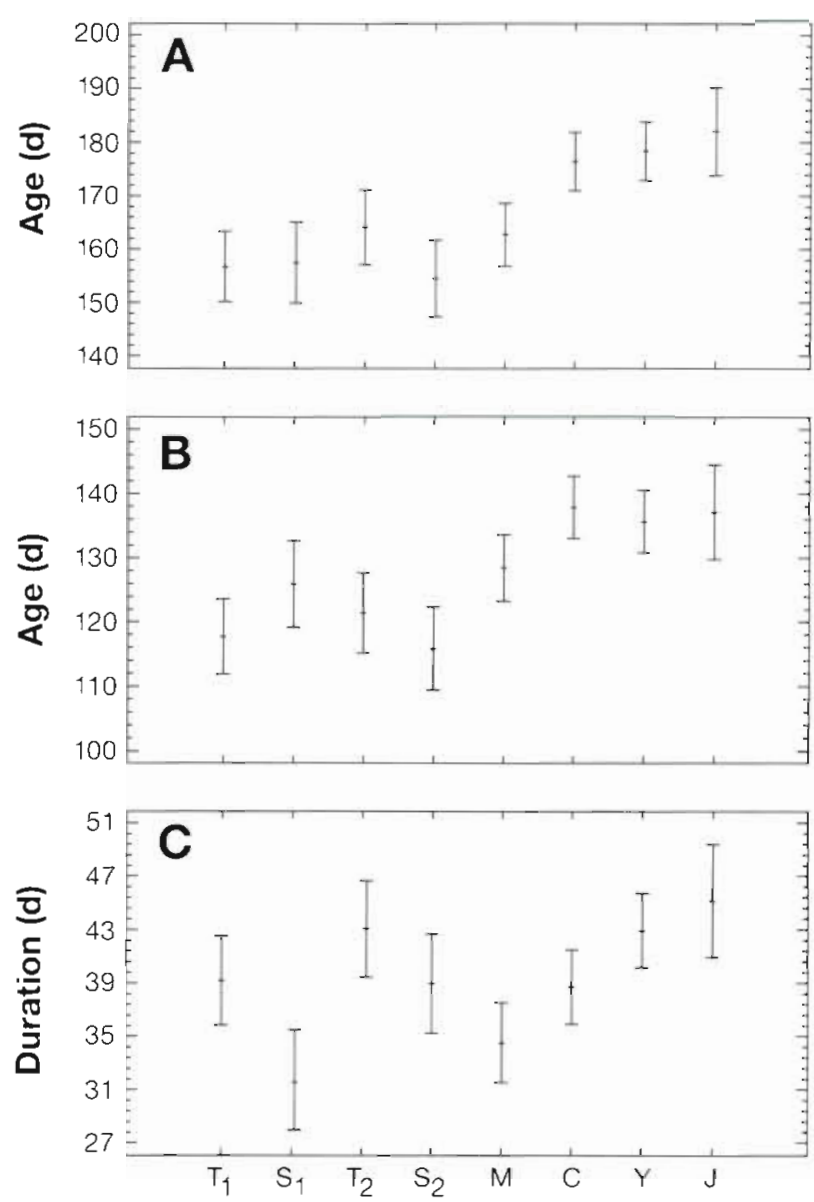

Fig. 6. Anguilla japonica. Geographic cline in (A) age of elvers arriving at 6 estuaries, (B) age of leptocephali at metamorphosis, and $(C)$ time between metamorphosis and arrival at estuaries. The 6 estuaries (T, S, M, C, Y and I) are shown in Fig. 1

ancy is probably due to the different methods used to count the otolith daily growth increments around the metamorphosis zone. Tsukamoto \& Umezawa (1990) indicated that otolith increment widths became larger during the period when leptocephali metamorphosed to glass eels. We found that increment widths became narrower in the area close to the metamorphosis check (Fig. 4), where fine daily growth increments were present (Fig. 5). Therefore, we believe that during the metamorphosing period otolith growth decreases and increment width becomes narrow, and, thus, we counted more increments.

The duration of the leptocephalus stage was 116 to $138 \mathrm{~d}$. A prolonged larval stage has also been found in other species, for example, 110 to $170 \mathrm{~d}$ for King George whiting Sillaginous punctata (Jenkins \& May 1994). Variation in the duration of the larval stage is an important factor in determining the distribution of a fish. In the absence of a suitable habitat for settlement, larvae may delay metamorphosis (Jackson \& Strathmann 1981, Victor 1986), a delay which may last for months in several species of invertebrates (Scheltema 1971, Hadfield 1978, Domanski 1984, Pechenik et al. 1984, Richmond 1985). This flexibility in time of settlement and metamorphosis allows the larvae enough time to disperse over great distances in order to find a suitable habitat (Scheltema \& Williams 1983, Christopher \& Leggett 1987). Interspecific variations in the length of the larval period and the time at which metamorphosis takes place depends on the early life history strategy of a species and on the hydrodynamic processes operating at the time of the dispersal (Jenkins \& May 1994)

The timing of the metamorphosis of a leptocephalus and transportation by the Kuroshio Current were considered to be important factors determining the ultimate destination of eels (Tsukamoto \& Umezawa 1994). The velocity of the Kuroshio Current averages 2.5 knots (range 2 to 3 knots), i.e. $96 \mathrm{~km} \mathrm{~d} \mathrm{~d}^{-1}(77$ to $116 \mathrm{~km} \mathrm{~d}^{-1}$ ) (Nitani 1972). The difference in mean ages of leptocephali at metamorphosis to glass eels estimated from the elvers collected at the 6 estuaries in this study was approximately $22 \mathrm{~d}$ (Table 5). This time lag allows the Kuroshio Current to disperse the leptocephali to a distance of about $2100 \mathrm{~km}$ at a velocity of 2.5 knots. This distance was very close to the estimated distance of approximately $2000 \mathrm{~km}$ between the northernmost and southernmost limits of the 6 estuaries studied (Fig. 1). This evidence suggests that the timing of the metamorphosis of the leptocephali and the Kuroshio Current play important roles in the longdistance dispersal of the Japanese eel.

The mean increment widths of the otoliths from the outer core to the metamorphosis check for the elvers collected at the 6 estuaries showed a geographic cline that decreased from south to north, but age at metamorphosis increased from south to north. These opposite trends in the geographic clines of otolith growth rate and age at metamorphosis indicated that the fastgrowing leptocephali metamorphosed earlier and migrated to the southern estuaries of the distribution range, while the slow-growing ones metamorphosed later and migrated to the northern estuaries of the range. Apparently, age at metamorphosis is an important factor in determining the southern limit of the distribution of the Japanese eel.

The Japanese eel is seldom found in Philippine waters (Tabeta et al. 1975, Tabeta et al. 1976), although the larvae migrate in that direction. The eel spawn in waters west of the Mariana Islands $\left(15^{\circ} \mathrm{N}\right.$, $140^{\circ} \mathrm{E}$ ), and their larvae drift with the North Equatorial Current at a speed of 20 to $32 \mathrm{~cm} \mathrm{~s}^{-1}$ (Kimura et al. 1994). Depending upon the speed of the current and the distance involved, larvae arrive in Philippine 
waters approximately 55 to $87 \mathrm{~d}$ after hatching. The age of the elvers at metamorphosis at the 6 estuaries studied in Taiwan, China and Japan averaged 116 to 138 d (Table 5). The leptocephali which arrive in Philippine waters are apparently too young to metamorphose and migrate toward estuaries. This may explain why the Japanese eel is seldom found in the Philippines.

Three fully grown leptocephali of Japanese eel were collected in the southeastern waters of Taiwan, between approximately $20^{\circ}$ and $22^{\circ} \mathrm{N}$. One of them had a TL of 55.80 and was 84 d old (Tanaka 1975, Tabeta \& Takai 1975a,b, Tsukamoto et al. 1992). Based on the age at metamorphosis ( 116 to 138 d) estimated in this study and the location of the fully grown leptocephali, the latitude where leptocephali may metamorphose to become glass eels was estimated to be in an area further north from Taiwan. If this is true, the migratory distance covered from the time of metamorphosis to the time of arrival at estuaries should be greater for elvers in the southern portion of Taiwan than for those in the northern portion (Fig. 1). This may explain why the time from metamorphosis to arrival at estuaries for the elvers collected at Site $\mathrm{T}\left(\mathrm{T}_{1} \& \mathrm{~T}_{2}\right)$ in southern Taiwan was longer than for those collected at Site $\mathrm{S}\left(\mathrm{S}_{1}\right.$ \& $\mathrm{S}_{2}$ ) in northern Taiwan (Fig. 6C). This also supports the hypothesis that elvers along the southwestern coasts of Taiwan are being carried by the China Coastal Current from the north (Tzeng 1985, 1986, Tzeng \& Tsai 1992)

In conclusion, age at metamorphosis and the lengthy duration of the leptocephalus stage are important factors determining the long-distance dispersal of the Japanese eel.

Acknowledgements. This study was financially supported by the National Science Council, Republic of China (Project No. NSC 852311B002032). The authors are grateful to Mr Y. H. Shieh and $\mathrm{Dr} \mathrm{K}$. Tsukamoto for providing the fish specimens from China and Japan, to Miss C. H. Wang, Miss C. E. Wu and $\mathrm{Mr} \mathrm{H}$. P. Wei for preparing the manuscript, and to Dr T F Tsai, Dr K. Severin and 3 anonymous reviewers for helpful comments.

\section{LITERATURE CITED}

Bertin L (1956) Eels - a biological study. Cleaver-Hume Press, London

Christopher RC, Leggett WC (1987) Size and age at metamorphosis in marine fishes: an analysis of laboratory-reared winter flounder (Pseudopleuronectes americarus) with a review of variation in other species. Can J Fish Aquat Scl $44: 1936-1947$

Domanski PA (1984) Giant larvae: prolonged planktonic larval phase in the asteroid Lundia sarsi. Mar Biol 80:189-195

Hadfield MG (1978) Growth and metamorphosis of planktonic larvae of Ptychodera flava (Hemichordata: Enterop- neusta). In: Chia FS, Rice ME (eds) Settlement and metamorphosis of marine invertebrate larvae. Elsevier, New York, p 247-254

Jackson GA, Strathmann RR (1981) Larval mortality from offshore mixing as a link between precompetent and competent periods of development. Am Nat 118:16-26

Jenkins GP, May HMA (1994) Variation in settlement and larval duration of King George whitıng, Sillagnodes punctata (Aillaginıdae), in Swan Bay, Victoria, Australia. Bull mar Sci 54(1):281-296

Kajihara T, Tsukamoto K, Otake T, Moritaka N, Hasumoto $\mathrm{H}$, Oya M, Tabeta $O$ (1988) Sampling leptocephall with reference to the diel vertical migration and the gears. Nippon Suisan Gakkaishi 54(6):941-946

Kimura S, Tsukamoto K, Sugimoto T (1994) A model for the larval migration of the Japanese eel: roles of the trade winds and salinity front. Mar Biol 119:185-190

Lecomte-Finiger R (1992) Growth history and age at recruitment of European glass eels (Anguilla anguilla) as revealed by otolith microstructure. Mar Biol 114:205-210

Nishizawa K (1978) Marine algae from a vlewpoint of pharmaceutical studies. Jap J Phycol 26:73-78

Nitani H (1972) Beginning of the Kuroshio. In: Stommel $H_{\text {, }}$ Yoshida K (eds) Kuroshio - its physical aspects. Univ Tokyo Press, p 129-163

Otake T, Ishil T, Nakahara M, Nakamura R (1994) Drastic changes in otolith strontium/calcium ratios in leptocephali and glass eels of Japanese eel Anguilla japonica. Mar Ecol Prog Ser 112:189-193

Pechenik JA, Scheltema RS, Eyeter LS (1984) Growth stasis and limited shell calcification in larvae of Cymatium parthenopeum during trans-Atlantic transport. Scjence 224:1097-1099

Pieiler E (1984) Glycosaminoglycan breakdown during metamorphosis of larval bone fish Albula. Mar Biol Lett 5: $241-249$

Pfeiler E (1986) Towards an explanation of the developmental strategy in leptocephalus larvae of marine teleost fishes. Environ Biol Fish 15:3-13

Pfeiler E (1991) Glycosaminoglycan composition of anguilliform and elopiform leptocephali. J Fish Biol 38:533-540

Richmond RH (1985) Reversible metamorphosis in coral planula larvae. Mar Ecol Prog Ser 22:181-185

Sang TK, Chang HY, Chen CT, Hui CF (1994) Population structure of the Japanese eel, Anguilla japonica. Mol Biol Evol 11(2):250-260

Sheltema RS (1971) Larval dispersal as a means of genetic exchange between geographically separated populations of shallow-water benthic marine gastropods. Biol Bull 140: $284-322$

Scheltema RS, Wilhams IP (1983) Long-distance dispersal of planktonic larvae and the biogeography and evolution of some Polynesian and Western Pacific mollusks. Bull mar Sci 33:545-565

Sokal RR, Rohlf FJ (1981) Biometry, 2nd edn. WH Freeman, San Francisco

Strubberg AC (1913) The metamorphosis of elvers as influenced by outward conditions. Meddr Kommn Danm FiskHavunders 4:1-11

Tabeta O. Takai T (1975a) Leptocephalus of Anguilla japonica found in the waters south of Taiwan. Jap J Ichthyol 22:100-103

Tabeta O. Takai T (1975b) Leptocephali of Anguilla japonica found in the waters south of the Okinawa Island. Nippon Suisan Gakkaıshi 41:137-145

Tabeta O. Takai T, Matsul I (1975) Record of the Japanese eel from the Philippines. Nippon Suisan Gakkaishi 41:641-644 
Tabeta O, Tanimoto T, Tanaka T. Matsui I, Imamura T (1976) Seasonal occurrence of angullid elvers in Cagayan River, Luzon Island, the Philippines. Nippon Suisan Gakkaishi $42: 421-426$

Tanaka S (1975) Collection of leptocephali of the Japanese eel in waters south of the Okindwa Island. Nippon Suisan Gakkaishı 41:129-136

Tesch FW (1977) The eel - biology and management of anguillid eels. Chapman \& Hall, London

Tsukamoto K (1990) Recruitment mechanism of the eel Anguilla japonica to the Japanese coast. J Fish Biol 36: $659-671$

Tsukamoto K (1992) Discovery of the spawning area for Japanese eel. Nature 356:789-791

Tsukamoto K, Umezawa A (1990) Early life history and oceanic migration of the eel Anguilla japonica. La Mer 28:188-198

Tsukamoto K, Umezawa A (1994) Metamorphosis: a key factor of larval migration determining geographic distribution and speciation of eels. In: Proceedings of 4 th IndoPacific fish conference, Bangkok, Thailand, 28 Nov-4 Dec 1993. Faculty of Fisheries, Kasetart University, p 231-248

Tsukamoto Y, Umezawa A, Tsukamoto K, Okiyama M (1992) A fully grown leptocephalus of Japanese eel collected from the western north Pacific. Nippon Suisan Gakkaishi 58:2209

This article was submitted to the editor
Tzeng WN (1985) Immigration timing and activity rhythms of the eel, Anguilla japonica, elvers in the estuary of northern Taiwan, with emphasis on environmental influences. Bull Jap Soc Fish Oceanogr 47/48:11-28

Tzeng WN (1986) Resources and ecology of the Japanese eel Anguilla japonica elvers in the coastal waters of Taiwan. China Fisheries Monthly 404:19-24 (in Chinese)

Tzeng WN (1990) Relationship between growth rate and age at recruitment of Anguilla japonica elvers in a Taiwan estuary as inferred from otolith growth increments. Mar Biol 107:75-81

Tzeng WN (1995) Migratory history recorded in otoliths of the Japanese eel, Angnilla japonica, elvers as revealed from SEM and WDS analysis. Zool Stud 34 (Suppl) 1 $234-236$

Tzeng WN, Tsai YC (1992) Otolith microstructure and daily age of Anguilla japonica Temminck \& Schlegel elvers from the estuaries of Taiwan with reference to unit stock and larval migration. J Fish Biol 40:845-857

Tzeng WN, Tsai YC (1994) Changes in otolith microchemistry of the Japanese eel, Anguilla japonica, during its migration from the ocean to the rivers of Taiwan. J Fish Biol 45 $671-684$

Victor BC (1986) Delayed metamorphosis with reduced larval growth in a coral reef fish (Thalassoma bifasciatum). Can J Fish Aquat Sci 43:1208-1213

Manuscript first received: May 26, 1995

Revised version accepted: September 26, 1995 